\title{
Obamas glemte udfordring
}

\section{Jens Lohmann}

En af Barack Obamas vigtigste opgaver bliver at genoprette det gode forhold til Latinamerika. Men det bliver op ad bakke, for Bush forsømte 'baggården', der har vendt blikket mod andre lande og regioner i forsøgene på at stå på egne ben. Men Latinamerika er samtidig et sprængfarligt problem for USA's nye præsident

En af de vigtigste, men ret oversete udenrigspolitiske udfordringer USA's nye præsident Barack Obama står overfor, er forholdet til USA's traditionelle baggård, Latinamerika.

Det meste af det såkaldte subkontinent har i løbet af George W. Bushs otte år i Det Hvide Hus bevæget sig ind på en uafhængig kurs i forhold til USA. Bush-regeringens næsten totale negligering af sine sydlige naboer har skabt en historisk stor afstand mellem Washington og de fleste latinamerikanske hovedstæder, som Obama og hans embedsmænd får vanskeligt ved at afkorte, trods Obamas erklærede gode vilje til at forbedre forholdet til de sydlige naboer, blandt andet i et hensigtsdokument, A new partnership for the Americas.
Spørgsmålet er, hvor dybt Obamas gode vilje over for Latinamerika stikker. Under valgkampen var den udenrigspolitiske fokus først og fremmest på krigen i Irak og på den globale finanskrise. Latinamerika blev næsten ikke nævnt under valgkampen - bortset fra en enkelt, kortfattet omtale fra Obama af den colombianske regerings manglende reaktion på mord på faglige ledere $\mathrm{i}$ Colombia, en omtale, der vist mere var beregnet på den amerikanske fagbevægelse, end den var udtryk for en speciel interesse for menneskerettighedernes elendige tilstand i Colombia, og en tale i maj 2008 til den eksilcubanske organisation CANF (Cuban American National Foundation) i Miami, hvor han blandt andet sagde, at "efter otte år 
med George Bushs katastrofale politik, er det på tide at bruge direkte diplomati uden forhåndsbetingelser, over for såvel ven som fjende" med direkte henvisning til forholdet til Cuba, der siden præsident Eisenhower har været åbenlyst fjendtligt. Uden at det er lykkedes at fjerne det kommunistiske styre på den grønne revolutionsø. Tværtimod har USA's økonomiske blokade og militære pres været med til at styrke regimet og legitimere undertrykkelsen. Ellers var der kun meget sporadiske omtaler af Latinamerika, specielt Cuba, under valgkampen.

\section{Vender ryggen til USA}

Barack Obama og hans rådgivere har uden tvivl set rigtigt, når de har formuleret en ny politik over for et Latinamerika, hvor en voksende national selvbevidsthed og uafhængig ageren på den internationale scene har fjernet nord og syd på den vestlige halvkugle fra hinanden. Ikke kun Venezuelas højtråbende præsident Hugo Chávez og andre venstreorienterede regeringer, men også mere moderate og borgerlige regeringer har helt eller delvist vendt USA ryggen og søgt nye partnere, der også synes ivrige efter at udfylde det delvise tomrum, Bush-regeringens manglende interesse for Latinamerika synes at have efterladt.

Der bliver rejst som aldrig før. Argentinas præsident Cristina Fernández besøgte således i midten af no- vember Egypten, Libyen, Tunesien og Algeriet. Især besøget i Algeriet er interessant, fordi den obligate samarbejdsaftale der blev undertegnet, omfatter samarbejde om energi og rumfart samt argentinsk bistand til udvikling af atomkraft.

Kinas præsident Hu Jintao besøgte Costa Rica og Cuba på vej til APEC-topmødet i Perus hovedstad Lima i slutningen af november 2008. APEC er den økonomiske samarbejdsorganisation for Asien og Stillehavsområdet. Næsten samtidig besøgte hans russiske kollega Brasilien, Peru, Cuba og Venezuela. I Venezuela faldt hans besøg sammen med at en russisk flådeenhed med den atomdrevne russiske krydser 'Peter den Store' i spidsen deltog i en stor, fælles venezuelansk-russisk flådeøvelse i Caribien.

Iran har udvidet handelen og samarbejdet med flere latinamerikanske lande. Irans præsident Mahmud Ahmadinejad var i 2007 den første iranske præsident, der besøgte Latinamerika, da han foretog en rundrejse til Venezuela, Nicaragua, Ecuador og Bolivia.

Bolivias præsident Evo Morales er kommet stadig mere på kant med USA, hvis ambassadør han udviste i september 2008 , idet han beskyldte ham for at blande sig i Bolivias indre anliggender ved at opfordre til uroligheder. Kort efter meddelte Morales, at visumtvangen for iranske statsborgere er ophævet, og at Bolivia ville flytte sin ambassade i Cairo 
til Teheran. I oktober åbnede Iran og Venezuela en fælles flyrute Caracas-Damaskus-Teheran.

Det er dog forskellige interesser, der ligger bag Kinas, Ruslands og Irans tilnærmelse til et kontinent, der er næsten totalt fraværende i de danske medier.

For det økonomisk ekspanderende Kina er det vigtigt at sikre sig rigelige og stabile forsyninger af råvarer og fødevarer. Her er Latinamerika et oplagt valg. Kontinentet er rigt på mineraler og olie, og har et stort potentiale for produktion af fødevarer - fra kød og fisk til ris, soja og bananer.

Rusland er også interesseret i Latinamerikas mineraler og fødevarer, men den russiske hovedinteresse i tættere forbindelser med Latinamerika ligger et helt andet sted. Dels i at manifestere over for USA, at Rusland er en storpolitisk spiller, der kan agere overalt på kloden, også helt op til USA's grænser på samme måde som USA gjorde med sin militære bistand til den tidligere sovjetrepublik Georgien. Det er det signal russerne sendte ved at lade flådens flagskib 'Peter den Store' vise flaget i Caribien.

Dels er Latinamerika blevet et vigtigt marked for den russiske våbenindustri. Med Venezuela som den største, men langtfra eneste køber, er Ruslands salg af våben og militært udstyr vokset fra 300 mio. dollar i 2001 til 3 mia. dollar i 2006. Dermed er Latinamerika blevet et af de vigtigste markeder for den russiske våbenindustri.

Irans interesse i at udbygge relationerne med Latinamerika er først og fremmest politisk. Det tætte forhold præstestyret efterhånden har udviklet til Venezuelas Hugo Chávez og via ham til andre latinamerikanske lande, tjener til at bryde den isolation landet efterhånden er kommet $\mathrm{i}$, især i forhold til Vesten, blandt andet på grund af de internationale sanktioner som følge af styrets atompolitik. Selv om socialisten, den caribiske gadedreng Hugo Chávez næppe er enig med det konservative og livsforskrækkede præstestyre i mange ting, er deres positioner som vigtige, olieeksporterende lande og deres fælles fjendskab til USA en vigtig spore til - indtil videre - at følges ad på den internationale scene.

Hvor dybt interessen for Latinamerika stikker hos disse nye 'venner' af kontinentet vil blive sat på prøve af den økonomiske krises realiteter. Formentlig vil det især være Kina, som vil holde fast på grund af de oplagte økonomiske interesser både $\mathrm{i}$ råstoffer og fødevarer, og $\mathrm{i}$ potentielle markeder, selv om krisen begrænser deres vækstmuligheder. Men på lidt længere sigt ligger der et stort potentiale for kineserne i Latinamerika, ikke mindst fordi USA's økonomiske tilstedeværelse vil være svækket.

De latinamerikanske lande har desuden den sidste halve snes år vist en større interesse for at udbygge 
samhandelen med andre lande og regioner, med EU, Sydøstasien og de arabiske lande som de mest interessante.

Foreløbig har Mexico og Chile indgået frihandelsaftaler med EU, mens flere af østaterne i Caribien er med i den særlige ACP-aftale, der omfatter fattige, tidligere europæiske kolonier i Afrika, Caribien og Stillehavet. Flere latinamerikanske præsidenters og ministres hektiske rejseaktivitet til Asien, Afrika, Mellemøsten og EU afspejler interessen for at bryde de traditionelt dominerende relationer med USA, og især satse på Syd-Syd-relationer.

Særlig Brasiliens intense diplomatiske aktivitet under den moderate socialist Luíz Inácio Lula da Silvas regering er værd at bide mærke i. Brasilien er blevet en økonomisk gigant, som ønsker at spille en hovedrolle internationalt. Lulas satsning for at få Brasilien anerkendt som én af de store er ved at lykkes. Sammen med Kina og Indien tages landet nu med i kredsen af økonomisk betydende lande, når der skal tages stilling til verdensøkonomien.

\section{Obamas nye syn}

Latinamerika er med andre ord på vej bort fra det USA, der ellers har domineret kontinentet økonomisk, politisk og militært i godt et århundrede. USA kan ikke længere opnå meget med det princip præsident Theodore Teddy Roosevelt (1901-09) baserede sin politik over for Latinamerika på: "Tal sagte og gå med en stor stok" - hvor stokken blev anvendt mere end den sagte (læs: venlige) tale. Ej heller den berygtede Monroe-doktrin fra 1823, hvor USA erklærede, at den vestlige halvkugle var dets interessesfære, som andre magter skulle holde sig fra, kan den kriseramte supermagt basere sin Latinamerika-politik på længere.

Det synes Barack Obama og hans rådgivere at have erkendt, hvis man skal tro det 13 siders dokument han udsendte under valgkampen i 2008, A new partnership for the Americas. Her lægges der op til at råde bod på Bush-regeringens mange fejltagelser og undladelsessynder over for de latinamerikanske lande. Problemet er blot, at dokumentet er holdt i generelle og til tider luftige vendinger uden at pege på ret mange substantielle forandringer i den hidtidige politik.

Flere kommentatorer i USA peger på at der er en genlyd af Franklin D. Roosevelts Gode Nabo-politik og John F. Kennedys Fremskridtsalliance i dokumentet, der har tre prioritetsområder:

- politisk frihed og demokrati;

- sikkerhed og frihed for frygt;

- fattigdomsbekæmpelse og skabelse af muligheder for de fattigste.

I dokumentet lægges der op til at den amerikanske udviklingsbistand skal fordobles, og Fredskorpset udvides kraftigt. Obama lægger både i dokumentet og i spredte udtalelser 
op til, at han vil fremme en udvidelse og reformering af de demokratiske institutioner, og til at USA skal samarbejde med det demokratiske venstre, inklusive Hugo Chávez i Venezuela, da han er en legitimt og demokratisk valgt præsident. Ifølge Obama er USA's relationer med Latinamerika sygnet hen som følge af "en fejlagtig udenrigspolitik med et nærsynet fokus på Irak”. Bush-regeringens "politik på den vestlige halvkugle (the Americas) har overset vore venner".

Ifølge Obama skal USA forlade den rodfæstede amerikanske tradition med kun at støtte regimer, der direkte fremmer USA's snævre nationale interesser. Og USA skal afstå fra at knytte personlige venskaber sammen med udenrigspolitik - en slet skjult hentydning til Bushs venskab med Colombias stærkt kontroversielle, konservative præsident Álvaro Uribe, der trods utallige løfter ikke har sørget for at mindske de mange alvorlige krænkelser af menneskerettighederne i Colombia.

Ét konkret resultat af Obamas erklærede politik over for Latinamerika kan blive, at den frihandelsaftale, som Bush og Uribe har underskrevet, og som siden juni 2008 har været strandet i Kongressen i Washington, primært på grund af menneskerettighedssituationen i Colombia, ikke bliver ratificeret. Det vil være et stort nederlag for Uribe. Uanset om frihandelsaftalen bliver ratificeret eller ej, er det tvivlsomt om det vil føre til en ende på de væbnede konflikter i landet. Frihandelsaftalen rummer en klausul om menneskerettigheder, som USA i givet fald ville kunne tage $i$ anvendelse over for Colombia.

Men menneskerettighedsklausuler er ingen garanti. Det viser EU's frihandelsaftale med Mexico. Krænkelserne af menneskerettighederne i Mexico er taget til gennem flere år. Især er ytringsfriheden under voldsomt pres. Mexico er således næst efter Irak det farligste land at være journalist i. Fra januar til november 2008 blev otte journalister myrdet $i$ Mexico, og flere journalister har måttet søge tilflugt i USA og Canada.

\section{Behov for troværdighed}

Det største problem for Barack Obama i forholdet til Latinamerika bliver at skabe en troværdighed og genvinde en del af USA's tabte indflydelse. Det kræver en tålmodig indsats med økonomisk bistand, der ikke er betinget af en bestemt politisk orientering, og økonomisk politik, som støtter menneskerettigheder og ikke mindst manifesterer en udtalt respekt for latinamerikanernes egne løsninger på de mange alvorlige problemer kontinentet lider under - fra den voldsomme sociale ulighed til politisk og narkorelateret vold og overgreb mod indfødte folk.

Sidst men ikke mindst kræver det en erkendelse af og respekt for, at 
latinamerikanerne kan ønske at gå andre veje, der traditionelt betragtes som suspekte eller farlige i USA. Hidtil har USA betragtet den såkaldte 'venstredrejning' i Latinamerika som farlig og uacceptabel - med Hugo Chávez' Venezuela og Evo Morales' Bolivia som skræmmeeksempler - uden at se på årsagerne til disse radikale udviklinger.

Begge lederes radikale og stærkt kritiske syn på USA har rod i den traditionelle amerikanske stillingtagen til fordel for højreorienterede og ofte undertrykkende regimer. Tankegangen fra præsident Franklin D. Roosevelt, da han i 1939 skal have sagt om Nicaraguas amerikansk støttede diktator Anastasio Somoza: "Somoza may be a son of a bitch, but he's our son of a bitch", må høre fortiden til, hvis Obama skal kunne skabe et tæt og ligeværdigt forhold til Latinamerika.

Det må indebære en nedtoning af den enøjede kritiske holdning til kontinentets mange mere eller mindre venstreorienterde regeringer, som alle - bortset fra Cubas - er demokratisk valgte. Og det må indebære en langt mere kritisk holdning til de USA-venlige, stærkt konservative regeringer $i$ to af regionens vigtigste lande, Mexico og Colombia.

\section{Columbia og Mexico}

Begge lande har i årevis været plaget af en tiltagende vold, som meget forenklet er blevet tilskrevet narko- kartellerne og narkohandelen. I Colombia med den tilføjelse, at guerillaen, først og fremmest den gammelkommunistiske FARC, spiller en nøglerolle for opretholdelsen af voldsspiralen. Dermed har såvel politikere som medier overset kernen i problemet, nemlig at staten i Colombia kontrolleres af en præsident, der har en meget tæt tilknytning til en af parterne i konflikten, nemlig de narkorelaterede, paramilitære grupper, og som desuden har myndighed over politi og militær, der er gennemkorrupte og i høj grad har blod på hænderne.

Bush-regeringens ambitiøse Plan Colombia, der skulle komme narkohandelen (og guerillaen) til livs, kan næppe kaldes en succes, selv om FARC er alvorligt svækket. I dag tæller bevægelsen knap 8000 personer under våben mod flere end $20.000 \mathrm{i}$ 2006. Men man overser, at et stort antal guerillaer er deserteret med deres våben $o g$ har sluttet sig til paramilitære grupper eller dannet egne banditgrupper, der begår overgreb mod civilbefolkningen - og i øvrigt er involveret i produktion og handel med narko.

Man overser også, at den hastigt tiltagende vold i Mexico i høj grad skyldes, at narkokarteller og andre grupper kæmper om det magttomrum, der er opstået i verdens 13 . største økonomi, olielandet Mexico, fordi skiftende regeringer siden 1990'erne har været plaget af interne opgør og grasserende korruption 
og har forsømt at løse landets stadig alvorligere sociale og økonomiske problemer. De mexicanske karteller har bånd til politikere på alle niveauer. Ifølge en mexicansk undersøgelse kontrollerer narkokartellerne direkte eller gennem tilknyttede politikere 54 procent af landets kommuner - de er feudaliseret, som det hedder. Flere delstater er ifølge forskerne godt på vej til samme situation.

Ligesom i Colombia er politi og militær på alle niveauer infiltreret eller købt af narkokartellerne, direkte eller gennem korrupte politikere. Den konservative præsident Felipe Calderón har ikke kontrol over landet. Han har med en usædvanlig snæver klan-mentalitet satset på at udnævne sine venner og kontakter til ministre og andre vigtige poster, og har derved splittet sit eget katolsk-konservative parti, PAN.

Han har skubbet den store opposition fra sig frem for at forsøge at skabe en national samling for at løse landets alvorlige problemer - en specielt alvorlig sag, når han i forvejen af en del af befolkningen betragtes som illegitim, fordi han ikke gik med til en fintælling af stemmerne efter valget i juli 2006, selv om der var beviser på uregelmæssigheder. Han blev udråbt som vinder med en margin på 0,56 procent.

De to lande er potentielt langt farligere krudttønder end de fleste af de lande, som styres af moderate og venstreorienterede regeringer, der seriøst - med forskelligt held - forsøger at løse deres respektive landes alvorlige problemer, fra fattigdom og ulighed til miljø og menneskerettigheder, samtidig med at de skal sørge for at ride den økonomiske krise af uden alt for alvorlige følger.

\section{Mellemamerika}

En tredje krudttønde er Mellemamerika, hvor de mexicanske narkokarteller især har fået fodfæste i Guatemala, og hvor både den kriminelle og den institutionelle vold er udbredt. Hverken i Honduras eller Guatemala har regeringerne - begge moderat reformorienterede - fuld kontrol over institutionerne eller landet.

I Nicaragua truer den tidligere sandinistiske revolutionshelt Daniel Ortegas vilkårlige énmandsstyre med at kaste landet ud i en politisk og social krise, som kan medvirke til at destabilisere Mellemamerika.

Den skærpede interne konflikt i Bolivia mellem de velstående lavlandsprovinser, der vil løsrive sig, og det fattige højland, der er præsident Evo Morales' vigtigste magtbase, er også en tikkende bombe, der kan påvirke flere af landene i Andes-regionen. Lysende Stis tilsyneladende genkomst i Peru kan genoplive den væbnede konflikt fra 1970'erne og 1980'erne.

Cuba er et særligt og følsomt kapitel. Fidel Castro dør muligvis i Obamas regeringstid. Obama har erklæ- 


\section{JENS LOHMANN}

ret sig rede til at mødes med Cubas præsident, lillebror Raúl Castro, uden forhåndsbetingelser. Men han vil ikke ophæve den 47 år lange økonomiske blokade, der har påført Cuba mange problemer, højst lempe nogle af bestemmelserne i blokaden.

Måske kan Obamas nye Latinamerika-politik medvirke til at løse nogle af problemerne i regionen. Men man skal ikke forvente at Latinamerika - bortset fra Cuba - vil få topprioritet i Washington, selv om Rusland udfordrer USA militært og Kina fortrænger USA fra dets hidtidige ledende økonomiske position $\mathrm{i}$ regionen.

De latinamerikanske regeringer er også mindre tilbøjelige til at vende sig mod Washington for at få hjælp til at løse deres problemer. De er ved at få øje på, at de måske kan gå meget langt ad vejen selv ved fælles hjælp. Regionale og bilaterale samarbejdsaftaler mellem landene kan blive et af midlerne. Syd-SydSyd-samarbejdet med lande i Afrika, Asien og Mellemøsten kan bidrage, og et tættere samarbejde med EU kan blive vigtigt.

Under alle omstændigheder kan Obama betyde et nyt og mere frugtbart kapitel i det traditionelt konfliktfyldte forhold mellem den nu vaklende kolos i nord og de stadig mere selvbevidste latinamerikanere i syd.

Jens Lohmann er journalist og forfatter specialiseret $i$ latinamerikanske forhold. 